\title{
Turvallista, ympäristöystävällistä ja kulttuurisesti tärkeää? Kotimaisuuden merkitys ruoan valinnassa
}

\author{
Mari Niva $^{1)}$, Ari Peltoniemi ${ }^{2}$, Kristiina Aalto ${ }^{3)}$ \\ 1) Kasvatustieteellinen tiedekunta, PL 9 (Siltavuorenpenger 10), 00014 Helsingin yliopisto, \\ mari.niva@helsinki.fi \\ ${ }^{2)}$ Matkailu-ja Ravintolapalvelut MaRa ry, Merimiehenkatu 29, 00150 Helsinki, \\ ari.peltoniemi@mara.fi \\ ${ }^{3)}$ Kuluttajatutkimuskeskus, PL 24 (Unioninkatu 40), 00014 Helsingin yliopisto, \\ kristiina.aalto@helsinki.fi
}

Aikaisemman tutkimuksen perusteella kotimaisen ruoan arvostus on noussut 2000-luvun kuluessa ja on hinnan, maun ja terveellisyyden ohella kuluttajille tärkeä tekijä ruokaa koskevissa valinnoissa. Kuluttajat liittävät alkuperään laatuun, turvallisuuteen, eläinten hyvinvointiin ja taloudellisiin olosuhteisiin liittyviä merkityksiä. Tässä artikkelissa tarkastelemme, missä määrin kuluttajat arvostavat kotimaista ruokaa, missä tuoteryhmissä ja mistä syistä. Tutkimus perustuu vuonna 2014 kerättyyn väestöä edustavaan internet-pohjaiseen kuluttajakyselyyn (N=1021), joka kerättiin osana Ruokamarkkinoiden toimivuus ja elintarvikemarkkinoiden hinnanmuodostus -hanketta (2013-2016). Tarkastelemme kuluttajien asenteita liittyen elintarvikkeiden kotimaisuuteen ja selvitämme, miten eri tuoteryhmät eroavat toisistaan siinä, missä määrin kuluttajat suosivat kotimaisia ja ulkomaisia tuotteita. Lisäksi tutkimme varianssianalyysia (ANOVA) käyttäen sukupuolen, iän, elämänvaiheen, asuinpaikan ja koulutuksen sekä syömistä koskevien motivaatiotekijöiden, kuten ruoan edullisuuden ja valmistuksen paikallisuuden, merkitystä kotimaisen ja ulkomaisen ruoan valinnassa. Tulosten mukaan jopa 87\% vastaajista ilmoitti ostavansa kotimaista ruokaa hyvin mielellään ja $11 \%$ melko mielellään. Yli yhdeksän kymmenestä vastaajasta oli täysin tai melko samaa mieltä siitä, että kotimaista ruokaa ostamalla voi tukea Suomen taloutta, että kotimaista elintarviketuotantoa tarvitaan huoltovarmuuden ylläpitämiseksi kriisitilanteissa ja että suomalaisen ruokakulttuurin ylläpitäminen edellyttää kotimaista ruoantuotantoa. Lähes yhtä moni uskoi, että kotimaista ruokaa kannattaa suosia ympäristösyistä. Kotimaisen ja ulkomaisen ruoan suosiminen vaihteli eri tuoteryhmissä. Vastaajat ilmoittivat ostavansa kotimaisia vaihtoehtoja erityisesti tuoretuotteissa, kuten maidossa, jogurtissa, leivässä, lihassa ja lihatuotteissa, mutta myös margariinissa ja esimerkiksi hiutaleissa. Esimerkiksi hedelmissä, makeisissa ja kekseissä ostettiin usein myös ulkomaisia tuotteita. Valintojen analyysissa löydettiin sosiodemografisten taustatekijöiden perusteella joitakin eroja. Varsinkin yli 60-vuotiaille kuluttajille kotimaisuudella oli suuri merkitys ruoan valinnassa. Samoin naiset, pariskunnat ja pienillä paikkakunnilla asuvat painottivat ruokavalinnoissaan muita enemmän kotimaisuutta. Kotimaista ostavat arvostivat muita enemmän tuotteiden tuttuutta, paikallisuutta, ympäristöystävällisyyttä ja sitä, ettei tuotannossa ole käytetty geenitekniikkaa. Tulokset kertovat, että suomalaiset kuluttajat suosivat kotimaista ruokaa niin asenteellisella kuin valintojen tasolla. Sosioekonomiset erot kertovat siitä, että kotimaisen ja ulkomaisen ruoan arvostus voi olla muuttumassa, sillä nuoret ja kaupungeissa asuvat suhtautuvat ulkomaiseen ruokaan muita myönteisemmin.

Asiasanat: alkuperä, kotimaisuus, kuluttajat, ruoankulutus, survey 


\section{Johdanto}

Kuluttajat niin Suomessa kuin muuallakin ovat entistä kiinnostuneempia elintarvikkeiden alkuperästä ${ }^{1}$ ja tuotantotavoista (Roininen ym. 2006, Regattieri ym. 2007). Schnettlerin ym. (2011) mukaan alkuperä on jopa hintaa tärkeämpi ruoan valintakriteeri. Myös aiemmat Suomessa tehdyt kuluttajakyselyt (Piiroinen ja Järvelä 2006, Peltoniemi ja Yrjölä 2012) osoittavat, että maun, hinnan ja terveellisyyden ohella alkuperällä, erityisesti kotimaisuudella, on suuri merkitys suomalaisten ruoan valinnassa. Peltoniemen ja Yrjölän (2012) mukaan kotimaisuuden tärkeys on entisestään kasvanut 2000-luvun kuluessa: vuoden 2005 kuluttajakyselyssä $76 \%$ vastaajista piti kotimaisuutta vähintään melko tärkeänä, kun vuonna 2011 samoin ajattelevien vastaajien osuus oli noussut jo 86 prosenttiin.

Kotimaassa tuotettua ruokaa suositaan monenlaisista syistä. Tuontielintarvikkeiden lisääntymisen voidaan nähdä heikentävän kotimaisen ruoantuotannon edellytyksiä, taloutta ja työllisyyttä. Lähellä tuotettua ruokaa voidaan myös pitää eettisempänä tai ympäristöystävällisempänä vaihtoehtona. Kuluttajien arvostuksiin vaikuttavat myös kotimaisen ja ulkomaisen ruoan laatuun, terveellisyyteen, turvallisuuteen ja hintaan liittyvät käsitykset. (Chambers ym. 2007, McEachern ym. 2010.)

Aikaisemmassa, erityisesti markkinoinnin, tutkimuksessa on tarkasteltu kuluttajien kotimaisia ja ulkomaisia tuotteita koskevia asenteita ja valintoja kuluttajaetnosentrismin (consumer ethnocentrism) käsitteen avulla (esim. Shankarmahesh 2006, Chryssochoidis ym. 2007, Fernandéz-Ferrin ym. 2015). Etnosentrinen kuluttaja kokee tuontituotteiden ostamisen epäisänmaalliseksi, sillä hän uskoo sen vahingoittavan kotimaan taloutta ja aiheuttavan työpaikkojen menetyksiä (Shimp ja Sharma 1987, Sharma ym. 1995, Chambers ym. 2007). Kuluttajaetnosentrismi lisää kuluttajien halukkuutta ostaa paikallista ruokaa (Bianchi ja Mortimer 2015).

Useissa kansainvälisissä tutkimuksissa on tarkasteltu erilaisten sosiodemografisten tekijöiden merkitystä kotimaisen ruoan suosimisessa. Chryssochoidis ym. (2007) osoittivat, että iäkkäät ja vähän koulutetut kuluttajat suhtautuivat varauksellisimmin ulkomailta tuotuihin elintarvikkeisiin. Myös Orthin ja Firbasovan (2003) tutkimuksessa iäkkäät kuluttajat olivat ruoan suhteen muita ikäryhmiä etnosentrisempiä. Juricin ja Worsleyn (1998) tulosten mukaan hyvätuloiset ja korkeasti koulutetut nuoret suhtautuivat ulkomailla tuotettuihin elintarvikkeisiin myönteisemmin kuin pienempituloiset ja alemman koulutuksen saaneet iäkkäämmät kuluttajat. Tirelli ym. (2016) puolestaan havaitsivat, että naisten ruokaan liittyvät mielipiteet olivat yleisesti miehiä etnosentrisempiä, kun taas ostopäätöstä tehtäessä miehet olivat naisia etnosentrisempiä. Poudan ym. (2010) tutkimuksessa suomalaiset suosivat voimakkaasti kotimaista broileria. Enemmistölle kuluttajista tuotteen suomalainen alkuperä oli riittävä tae tuotteen korkeasta laadusta.

Aikaisempi tutkimus viittaa siis siihen, että etnosentrismillä on merkitystä ruoan valinnassa. Tuotevalintoja käsittelevässä tutkimuksessa paljon käytetty kuluttajaetnosentrismin käsite keskittyy kuitenkin melko kapeasti kulutuksen taloudellisten vaikutusten näkökulmaan ja oman maan talouden tukemiseen. Valinnoissa kotimaisten ja ulkomaisten valintojen välillä on todennäköisesti kuitenkin kyse paljosta muustakin kuin taloudellisista vaikutuksista. Tässä artikkelissa laajennamme kuluttajaetnosentrismin käsitettä tarkastelemalla sitä, millaisia muitakin kuin taloudellisia näkökulmia kuluttajat liittävät kotimaiseen ${ }^{2}$ ruokaan ja nimitämme myönteistä suhtautumista ja kotimaisen ruoan suosimista valinnoissa ruokaetnosentrismiksi. Analysoimme sitä, missä määrin kuluttajat arvostavat kotimaista ruokaa erilaisilla asenteellisilla ulottuvuuksilla sekä sitä, miten sosiodemografiset ja syömisen motivaatioihin liittyvät taustamuuttujat selittävät kotimaisen ja ulkomaisen ruoan valintaa.

\section{Materiaali ja menetelmät}

Tutkimuksen aineistona on vuoden 2014 joulukuussa toteutettu internet-pohjainen kuluttajakysely. Kyselyn tavoitteena oli selvittää elintarvikkeiden eri ominaisuuksien tärkeyttä suomalaisille kuluttajille, valintojen taustatekijöitä sekä näihin liittyviä sosiodemografisia eroja. Kysely toteutettiin osana

\footnotetext{
${ }^{1}$ Elintarvikkeen alkuperällä viitataan yleensä tiettyyn maantieteelliseen alueeseen (region of origin, ROO) tai varsinkin alkuperämaahan (country of origin, COO). Leen ja Ganeshin (1999) määritelmän mukaan alkuperämaa on mielikuva tai ulkoinen muuttuja, joka tiivistää tiedon ja toimii kuluttajan ostopäätöksenteon apuna.

${ }^{2}$ Chambersin ym. (2007) määritelmän mukaisesti tässä artikkelissa kotimaisella ruoalla tarkoitetaan maan rajojen sisällä tuotettua ja ulkomaisella ruoalla maan rajojen ulkopuolella tuotettua ruokaa.
} 
Ruokamarkkinoiden toimivuus ja elintarvikemarkkinoiden hinnanmuodostus -hanketta (2013-2016). Kyselyn teknisestä toteutuksesta vastasi Taloustutkimus Oy.

Vastaajien ( $\mathrm{N=1021)} \mathrm{joukossa} \mathrm{oli} \mathrm{hieman} \mathrm{enemmän} \mathrm{miehiä} \mathrm{(53 \% )} \mathrm{kuin} \mathrm{väestössä} \mathrm{(49 \%} \mathrm{vuonna} \mathrm{2014)}$ (Tilastokeskus 2016). Sukupuolen ja asuinpaikan suhteen aineisto edustaa kuitenkin hyvin väestöä. Yli 60-vuotiaiden osuus vastaajista (43\%) oli suurempi kuin koko väestössä (33\%) ja aineistossa oli hieman vähemmän perusasteen koulutusasteen saaneita (18\%) ja enemmän korkeasti koulutettuja (27\%) kuin väestössä (26\% ja 21\%).

Seuraavassa luvussa tarkastelemme ristiintaulukoinnin avulla sitä, millä tavoin kotimaista ruokaa koskevat asenteet ovat yhteydessä vastaajien sukupuoleen ja ikään. Asenneväittämät esitetään ristiintaulukoinnin tulokset sisältävässä Taulukossa 1. Kotimaisten ja ulkomaisten elintarvikkeiden valintaa analysoimme yksisuuntaisella ja monisuuntaisella varianssianalyysilla. Varianssianalyysissa käytetty selitettävä muuttuja muodostettiin kotimaisuuden tärkeyttä eri elintarvikkeita koskevissa valinnoissa selvittäneestä kysymyksestä. Mukana olleet elintarvikkeet olivat leipä, hiutaleet, tuore liha, lihaleikkeleet, tuore kala, einekset ja valmisruoat, juusto, maito, jogurtti, tuoreet kasvikset, pakastevihannekset ja -juurekset, hedelmät, pakastemarjat, makeiset, keksit, sekä margariinit ja muut rasvalevitteet. Kysymys kuului seuraavasti: ”Valitessasi ruokaa kaupassa, kuinka tärkeää kotimaisuus on sinulle seuraavissa tuotteissa? Kotimaisuudella tarkoitetaan sitä, että suurin osa sen raaka-aineista ovat kotimaisia. Valitse vaihtoehto 1, jos ostat aina kotimaista ja vaihtoehto 9, jos ostat aina ulkomaista. Jos valitset vaihdellen kotimaisia ja ulkomaisia elintarvikkeita, valitse sopivin vaihtoehto asteikolta. Jos et koskaan osta tuotetta, valitse vaihtoehto 10.” Vaihtoehto 10, en osta tuotetta lainkaan, koodattiin puuttuvaksi tiedoksi, minkä jälkeen muodostettiin jatkuva keskiarvomuuttuja (vaihteluväli 1-9) edustamaan kaikkia kuuttatoista elintarviketta. Varianssianalyysissa kutakin selittävän muuttujan luokkaa verrataan referenssiluokkaan siten, että negatiiviset arvot tarkoittavat kotimaisen suosimista ja positiiviset arvot ulkomaisen suosimista referenssiluokkaa enemmän. Selittävinä muuttujina ovat sosiodemografiset muuttujat ja syömisen motivaatioita mittaavat muuttujat (Taulukko 2).

Syömisen motivaatioita selvitettiin kysymyksellä, jossa vastaajaa pyydettiin arvioimaan, kuinka tärkeitä erilaiset ruokaan liittyvät asiat ovat hänelle. Analyysiin valittiin kahdeksan motivaatiomuuttujaa, joiden oletimme aikaisemman kirjallisuuden perusteella olevan yhteydessä kotimaisen ja ulkomaisen ruoan valintaan. Motivaatiomuuttujien alkuperäinen viisiportainen vastausasteikko luokiteltiin analyysissa kaksiportaiseksi: 1 = ei tärkeä ja ("ei lainkaan tärkeä”, "ei kovin tärkeä” ja "en osaa sanoa”), 2 = tärkeä ("melko tärkeä” ja "erittäin tärkeä”).

\section{Tulokset}

\section{Kotimaiseen ruokaan liittyvät asenteet ja ruokaetnosentrismi}

Kotimaisuutta koskevien asenneväittämien tulokset iän ja sukupuolen suhteen esitetään Taulukossa 1. Ruokaetnosentrismi oli erityisen vahvasti läsnä, kun vastaajilta pyydettiin arvioita kotimaisen ruoan ostamisen vaikutuksista Suomen talouteen: lähes kaikki vastaajat olivat vähintään jokseenkin samaa mieltä siitä, että kotimaista ruokaa ostamalla tuetaan Suomen taloutta. Naiset olivat miehiä vahvemmin tällä kannalla, sen sijaan eri ikäryhmien väliset erot olivat vähäisiä.

Yli yhdeksän kymmenestä vastaajasta oli täysin tai melko samaa mieltä myös siitä, että kotimaista elintarviketuotantoa tarvitaan huoltovarmuuden ylläpitämiseksi kriisitilanteissa, että suomalaisen ruokakulttuurin ylläpitäminen edellyttää kotimaista ruoantuotantoa ja että kotimaista ruokaa kannattaa suosia ympäristösyistä. Iäkkäistä suurempi osa kuin nuorista piti kotimaista ruokaa suomalaisen ruokakulttuurin ylläpitämisen edellytyksenä ja katsoi, että ympäristösyiden vuoksi kannattaa suosia kotimaista ruokaa. Samoin naisista suurempi osa kuin miehistä uskoi, että ympäristösyiden vuoksi on syytä suosia kotimaista ruokaa.

Lähes yhdeksän kymmenestä vastaajasta uskoi, että kotimainen ruoka on ulkomaista turvallisempaa. Naiset olivat suomalaisen ruoan turvallisuuden suhteen miehiä luottavaisempia ja pitivät miehiä useammin kotimaisia elintarvikevalmistajia luotettavampina kuin ulkomaisia. Useimmat vastaajat katsoivat myös kotimaisen ruoan olevan hintansa arvoista. Tuotantoeläinten hyvinvoinnin suhteen vastaajat olivat jossain määrin epävarmempia. 
Taulukko 1. Täysin tai jokseenkin samaa mieltä asenneväittämien kanssa olevat sukupuolen ja ikäryhmän mukaan (\%, P-arvot)

\begin{tabular}{|c|c|c|c|c|c|c|c|c|c|}
\hline & \multicolumn{3}{|c|}{ Sukupuoli } & \multicolumn{5}{|c|}{ Ikäryhmä } & \multirow[t]{2}{*}{ Kaikki } \\
\hline & miehet & naiset & Sig. & $18-29$ & $30-44$ & $45-59$ & $60+$ & Sig. & \\
\hline $\begin{array}{l}\text { Ostamalla kotimaista ruokaa voi tukea } \\
\text { Suomen taloutta. }\end{array}$ & 94 & 98 & $* *$ & 96 & 96 & 95 & 97 & & 96 \\
\hline $\begin{array}{l}\text { Kotimaista elintarviketuotantoa } \\
\text { tarvitaan huoltovarmuuden } \\
\text { ylläpitämiseksi kriisitilanteissa. }\end{array}$ & 96 & 96 & & 94 & 96 & 94 & 97 & & 96 \\
\hline $\begin{array}{l}\text { Suomalaisen ruokakulttuurin } \\
\text { ylläpitäminen edellyttää kotimaista } \\
\text { ruoan tuotantoa. }\end{array}$ & 92 & 93 & & 85 & 94 & 92 & 95 & $* *$ & 93 \\
\hline $\begin{array}{l}\text { Kotimaista ruokaa kannattaa suosia } \\
\text { ympäristösyistä. }\end{array}$ & 86 & 95 & $* * *$ & 85 & 94 & 91 & 91 & $*$ & 91 \\
\hline $\begin{array}{l}\text { Kotimainen ruoka on turvallisempaa } \\
\text { kuin ulkomainen. }\end{array}$ & 85 & 92 & $* *$ & 84 & 90 & 86 & 90 & & 88 \\
\hline $\begin{array}{l}\text { Suomessa tuotantoeläimiä ei kohdella } \\
\text { sen paremmin kuin muissakaan maissa. }\end{array}$ & 43 & 39 & & 41 & 39 & 41 & 41 & & 41 \\
\hline $\begin{array}{l}\text { Kotimainen ruoka ei ole hintansa } \\
\text { arvoista. }\end{array}$ & 24 & 21 & & 26 & 20 & 19 & 25 & & 22 \\
\hline $\begin{array}{l}\text { En luota kotimaisiin } \\
\text { elintarvikevalmistajiin enempää kuin } \\
\text { ulkomaisiinkaan. }\end{array}$ & 25 & 15 & $* * *$ & 23 & 18 & 19 & 22 & & 20 \\
\hline
\end{tabular}

\section{Valinta kotimaisen ja ulkomaisen ruoan välillä}

Valintaa kotimaisen ja ulkomaisen ruoan välillä koskeneessa kysymyksessä oli mukana yhteensä kuusitoista elintarviketta. Tuotekohtaiset suorat jakaumat kertoivat ruokaetnosentrismistä valinnoissa (ei taulukkoa). Erityisesti maidon ja leivän, mutta myös tuoreen lihan kaltaisissa peruselintarvikkeissa kotimaisia vaihtoehtoja suosittiin erityisen paljon. Noin 90\% vastaajista ilmoitti ostavansa aina tai lähes aina kotimaista maitoa ja leipää. Sitä vastoin makeisissa, kekseissä ja hedelmissä kotimaisuus vaikutti valintaan vähemmän kuin muissa elintarvikkeissa. Näissä tuoteryhmissä ulkomaisia vaihtoehtoja on myös paljon tarjolla ja esimerkiksi hedelmissä kotimainen tarjonta on varsin rajallista.

Yksisuuntaisen varianssianalyysin tulosten mukaan (Taulukko 2) ikäryhmä, sukupuoli, elämänvaihe ja asuinpaikka olivat yhteydessä valintoihin kotimaisen ja ulkomaisen ruoan välillä. Sosiodemografisista muuttujista vain koulutuksella ei ollut tilastollisesti merkitsevää yhteyttä valintoihin. Samoin motivaatiomuuttujista suurin osa oli yhteydessä kotimaisen ja ulkomaisen ruoan valintaan: tuttuus, tuotantoeläinten kasvatusolot, paikallisuus, ympäristöystävällisyys, se, että tuote on luomua ja että tuotannossa ei ole käytetty geenitekniikkaa olivat kaikki tilastollisesti merkitseviä.

Mallissa 1 tarkasteltiin kaikkia sosiodemografisia muuttujia samanaikaisesti. Nuoret, miehet ja suurissa kaupungeissa asuvat suosivat muita useammin ulkomaisia vaihtoehtoja. Mallissa 2 otettiin sosiodemografisten muuttujien lisäksi tarkasteluun mukaan motivaatiomuuttujat. Tässä mallissa merkitseviä olivat sosiodemografisista muuttujista ikä ja asuinpaikka sekä ruoan valinnan motivaatioista tuttuus, valmistus lähellä, ympäristöystävällinen tuotantotapa sekä tuotanto ilman geenitekniikkaa.

\section{Tulosten tarkastelu}

Tulokset tukevat aiempien tutkimusten tuloksia (Shimp ja Sharma 1987), joiden mukaan kuluttajaetnosentrismi on yleistä kehittyneissä teollisuusmaissa, joissa luotetaan kotimaisiin tuotteisiin enemmän kuin tuontituotteisiin (Papadopoulos ym. 1990, Wang ja Chen 2004) ja kotimaisen ruoan hankinnalla pyritään tukemaan oman maan taloutta (vrt. Chambers ym. 2007). Myös Suomessa on nähtävissä taloudelliseen näkökulmaan pohjautuvaa kuluttajaetnosentrismiä, sillä jopa $96 \%$ vastaajista katsoi, että kotimaista ruokaa ostamalla voi tukea kotimaan taloutta. Tulosten perusteella ruoan kulutuksessa etnosentrismillä on kuitenkin muitakin kuin taloudellisia ulottuvuuksia, joita kuvaamaan olemme käyttäneet laajempaa ruokaetnosentrismin käsitettä. Kotimaista ruokaa koskevia näkemyksiä 
mittaavat asennekysymykset osoittivat, että suomalaiset suhtautuvat kotimaiseen ruokaan erittäin myönteisesti ja ovat ruokaetnosentrisiä monilla ulottuvuuksilla.

Tulokset osoittivat, että yli 60-vuotiaat kuluttajat suhtautuivat Suomessa tuotettuun ruokaan muita myönteisemmin ja nuorille kuluttajille (18-29-vuotiaat) kotimaisuudella näytti olevan jonkin verran vähemmän myönteisiä merkityksiä kuin muille ikäryhmille. Tämä koskee erityisesti kotimaisen ruoan ympäristöystävällisyyttä ja merkitystä ruokakulttuurissa. Naiset suhtautuivat miehiä myönteisemmin varsinkin kotimaisen ruoan turvallisuuteen ja ympäristöystävällisyyteen. Tulokset ovat siten samansuuntaisia kuin aikaisemmat kansainväliset havainnot: naiset ja iäkkäät suhtautuvat kotimaiseen ruokaan erityisen myönteisesti (Orth ja Firbasova 2003, Tirelli ym. 2016).

Valintoja koskevan varianssianalyysin tulokset osoittivat samankaltaisia sosiodemografisia eroja kuin edellä kuvatut asennekysymykset. Mitä iäkkäämmästä kuluttajasta oli kyse, sitä useammin hän kertoi valitsevansa kotimaisen elintarvikkeen. Nuorin ikäryhmä valitsi muita useammin myös ulkomailla tuotettuja elintarvikkeita. Syynä saattaa olla, että nuoret ovat vanhempia ikäpolvia avoimempia uudenlaisten elintarvikkeiden ja ruokaelämysten suhteen sekä vähemmän vastaanottavaisia kulttuurisille stereotypioille (ks. Juric ja Worsley 1998, Chryssochoidis ym. 2007). Nähtäväksi jää, onko nuorten ennakkoluulottomampi suhtautuminen ulkomaisiin elintarvikkeisiin pysyvämpi sukupolviilmiö, vai muuttaako ikääntyminen ja perheen perustaminen suhtautumista kotimaisuutta suosivampaan suuntaan.

Muut sosiodemografiset muuttujat selittivät kotimaisten elintarvikkeiden valintoja samaan tapaan kuin kotimaisuutta koskevia asenteita. Naiset, kaksin puolisonsa kanssa elävät ja pienillä paikkakunnilla asuvat valitsivat kotimaista ruokaa useammin kuin muut. Koulutuksen suhteen erot eivät olleet tilastollisesti merkitseviä. Koulutuksella näyttää siten suomalaisessa yhteiskunnassa olevan vähemmän merkitystä ruokaan liittyvässä etnosentrismissä kuin monissa muissa maissa (ks. Juric ja Worsley 1998, Chryssochoidis ym. 2007). Tulos viittaa siihen, että kotimaisen ruoan arvostus ja valinta eivät ole samalla tavoin sosiaalisen aseman mukaan kerrostuneita kuin vaikkapa eettinen kulutus (esim. Niva ym. 2014), vaan kotimaisuutta arvostetaan kaikissa kansankerroksissa.

Valintoihin liittyvien motivaatioiden analyysi kertoi, että kotimaisen ruoan valintaan olivat yhteydessä tuttuuden, lähellä tapahtuvan ja ympäristöystävällisen tuotannon sekä geenitekniikan välttämisen pitäminen tärkeänä. Kiinnostavaa kyllä, hyvän maun tai edullisen hinnan arvostaminen ei erotellut valintoja kotimaisen ja ulkomaisen ruoan välillä. Vaikka julkisessa keskustelussa kotimaista ruokaa usein moititaan kalliiksi, tulostemme perusteella edullista hintaa arvostavat kuluttajat eivät näytä suosivan muita enemmän ulkomaista ruokaa.

\section{Johtopäätökset}

Tutkimuksen perusteella suomalaisten kuluttajien arvostus kotimaassa tuotettuja elintarvikkeita kohtaan on korkealla. Aikaisemmassa tutkimuksessa on esitetty, että etnosentrismi voi johtaa siihen, että kotimaista ruokaa suositaan vinoutuneiden mielikuvien perusteella ja että kotimaisen ruoan suosiminen voi olla näkymätön kaupan este (Shankarmesh 2006, Chryssochoidis ym. 2007). Ottamatta kantaa siihen, ovatko kuluttajien mielikuvat perusteltuja vai eivät, tuloksemme kertovat, että suomalaisten usko kotimaisen ruoan ympäristöystävällisyyteen, turvallisuuteen, ruokakulttuuriseen ja taloudelliseen merkitykseen on vahva. Tähän voi olla monia syitä, kuten voimistuva keskustelu ruoantuotannon ja kulutuksen kestävyydestä ja se, että Suomessa on vältytty suurilta kotimaiseen ruokaan liittyviltä ruokaskandaaleilta. Lisäksi, kuten Shankarmahesh (2006) on huomauttanut, etnosentrismi usein institutionalisoituu paikallista tuotantoa suosiviin julkisiin hankintoihin. Lähialueiden ruokatuotantoa suosiviin hankintoihin pyritään monissa kunnissa, ja niin yritysten ja etujärjestöjen kampanjat kuin poliittiset strategiat esimerkiksi lähiruoan edistämiseen ja ruokapolitiikkaan (Maa- ja metsätalousministeriö 2013, Valtioneuvosto 2016) liittyen vetoavat erilaisin argumentein kotimaisuuden puolesta. Esimerkiksi valmisteilla olevassa ruokapoliittisessa selonteossa tavoitteeksi asetetaan, että "vuonna 2030 suomalaiset kuluttajat syövät kestävästi ja eettisesti tuotettua kotimaista, maukasta, terveellistä ja turvallista ruokaa" (Valtioneuvosto 2016: 6). Kiinnostavaa olisikin tutkia tarkemmin kotimaiseen ruokaan julkisessa keskustelussa ja markkinoinnissa liitettyjä merkityksiä, jotka osaltaan muokkaavat sitä mielipideilmastoa, jossa kuluttajien arkiset syömisen käytännöt muotoutuvat. 
Taulukko 2. Kotimaisen ja ulkomaisen ruoan valinta: yksisuuntainen ja monisuuntainen (mallit 1 ja 2 ) varianssianalyysi (ANOVA)

\begin{tabular}{|c|c|c|c|c|}
\hline & $\mathbf{n}$ & Yksisuuntainen & Malli 1 & Malli 2 \\
\hline \multicolumn{5}{|l|}{ Sosiodemografiset muuttujat } \\
\hline Ikäryhmä & & $33.640 * * *$ & $27.050 * * *$ & $17.960 * * *$ \\
\hline $18-29$ & 137 & $0(a)$ & $0(a)$ & $0(a)$ \\
\hline $30-44$ & 173 & $-0.234^{*}$ & $-0.224 *$ & $-0.027^{*}$ \\
\hline $45-59$ & 276 & $-0.6 * * *$ & $-0.553 * * *$ & $-0.331 * * *$ \\
\hline 60 ja yli & 433 & $-0.806 * * *$ & $-0.770 * * *$ & $-0.514^{* * *}$ \\
\hline Sukupuoli & & $5.229 *$ & $14.365 * * *$ & 1.149 \\
\hline Mies & 539 & $0(a)$ & $0(a)$ & $0(\mathrm{a})$ \\
\hline Nainen & 480 & $-0.14^{*}$ & $-0.221 * * *$ & -0.059 \\
\hline Elämänvaihe & & $7.547 * * *$ & 1.522 & 0.613 \\
\hline lapsiperhe & 194 & $0(\mathrm{a})$ & $0(\mathrm{a})$ & $0(\mathrm{a})$ \\
\hline Yksinasuva & 277 & -0.07 & -0.09 & -0.016 \\
\hline Pariskunta & 507 & $-0.266 * *$ & -0.108 & -0.038 \\
\hline Muu & 41 & 0.299 & 0.157 & 0.150 \\
\hline Koulutus & & 2.151 & 1.097 & 0.945 \\
\hline peruskoulu/kansakoulu & 182 & $0(\mathrm{a})$ & $0(\mathrm{a})$ & $0(\mathrm{a})$ \\
\hline ammattikoulu/ylioppilas/opisto & 561 & 0.035 & -0.025 & -0.031 \\
\hline ammattikorkea/yliopisto/korkeakoulu & 276 & 0.166 & 0.077 & 0.055 \\
\hline Asuinpaikka & & $7.411 * * *$ & $5.088 *$ & $5.339 * *$ \\
\hline pk-seutu (Hki, Espoo, Vantaa, Kauniainen) & 220 & $0(\mathrm{a})$ & $0(\mathrm{a})$ & $0(a)$ \\
\hline muu yli 100000 as. kaupunki & 193 & -0.036 & -0.116 & 0.000 \\
\hline muu kaupunki & 415 & $-0.299 * * *$ & $-0.270 * *$ & $-0.213^{* *}$ \\
\hline muu kunta & 191 & $-0.322 * *$ & $-0.287 * *$ & $-0.227 * *$ \\
\hline \multicolumn{5}{|l|}{ Motivaatiomuuttujat } \\
\hline \multicolumn{5}{|l|}{ Minulle on tärkeää, että syömäni ruoka } \\
\hline maistuu hyvältä & & 0.651 & & 0.149 \\
\hline ei tärkeää & 25 & $0(\mathrm{a})$ & & $0(\mathrm{a})$ \\
\hline tärkeää & 994 & -0.159 & & 0.066 \\
\hline on tuttua & & $47.439 * * *$ & & $32.896 * * *$ \\
\hline ei tärkeää & 387 & $0(a)$ & & $0(a)$ \\
\hline tärkeää & 632 & -0.424 & & $-0.314 * * *$ \\
\hline on edullista & & 2.099 & & 3.285 \\
\hline ei tärkeää & 184 & $0(\mathrm{a})$ & & $0(\mathrm{a})$ \\
\hline tärkeää & 835 & 0.115 & & 0.125 \\
\hline on valmistettu lähellä & & $200.748 * * *$ & & 68.023*** \\
\hline ei tärkeää & 406 & $0(a)$ & & $0(a)$ \\
\hline tärkeää & 613 & $-0.809 * * *$ & & $-0.515^{* * *}$ \\
\hline on luomua & & $43.588 * * *$ & & 1.800 \\
\hline ei tärkeää & 737 & $0(a)$ & & $0(\mathrm{a})$ \\
\hline tärkeää & 282 & $-0.442 * * *$ & & -0.089 \\
\hline on tuotettu ympäristöystävällisesti & & $96.287 * * *$ & & $14.743 * * *$ \\
\hline ei tärkeää & 264 & $0(a)$ & & $0(a)$ \\
\hline tärkeää & 755 & $-0.655 * * *$ & & $-0.275^{* * *}$ \\
\hline on tuotettu ilman geenitekniikkaa & & $74.813^{* * *}$ & & $5.504^{*}$ \\
\hline ei tärkeää & 383 & $0(a)$ & & $0(a)$ \\
\hline tärkeää & 636 & $-0.527 * * *$ & & $-0.144^{*}$ \\
\hline \multicolumn{5}{|l|}{ tuotantoeläinten kasvatusolosuhteet ovat } \\
\hline hyvät & & $55.507 * * *$ & & 0.028 \\
\hline ei tärkeää & 204 & $0(a)$ & & $0(\mathrm{a})$ \\
\hline tärkeää & 815 & $-0.555 * * *$ & & -0.013 \\
\hline
\end{tabular}

*** $\mathrm{P}<0.001,{ }^{* *} \mathrm{P}<.001,{ }^{*} \mathrm{P}<.05$; (a)=referenssiluokka 


\section{Kiitokset}

Tutkimus tehtiin osana Ruokamarkkinoiden toimivuus ja elintarvikkeiden hinnanmuodostus Suomessa sekä Ruokamarkkinoiden muuttuvat rakenteet ja kilpailun toimivuus -tutkimushankkeita. Kiitämme rahoituksesta maa- ja metsätalousministeriötä.

\section{Kirjallisuus}

Bianchi, C. \& Mortimer, G. 2015. Drivers of local food consumption: a comparative study. British Food Journal 117: 2282-2299.

Chambers, S., Lobb, A., Butler, L., Harvey, K. \& Traill, B. 2007. Local, national and imported foods: A qualitative study. Appetite 49: 208-213.

Chryssochoidis, G., Krystallis, A. \& Perreas, P. 2007. Ethnocentric beliefs and country-of-origin (COO) effect. European Journal of Marketing 41: 1518-1544.

Fernández-Ferrín, P., Bande-Vilela, B., Klein, J. G. \& del Rio-Araújo, M. 2015. Consumer ethnocentrism and consumer animosity: antecedents and consequences. International Journal of Marketing 10: 73-88.

Juric, B. \& Worsley, A. 1998. Consumers' attitudes towards imported food products. Food Quality and Preference 9: 431-441.

Kurunmäki, S., Ikäheimo, I., Syväniemi, A.M. \& Rönni, P. 2012. Lähiruokaselvitys: ehdotus lähiruokaohjelman pohjaksi. Helsinki: Maa- ja metsätalousministeriö.

Lee, D. \& Ganesh, G. 1999. Effects of partitioned country image in the context of brand image and familiarity. International Marketing Review 16: 18-41.

Maa- ja metsätalousministeriö 2013. Lähiruokaa - totta kai! Hallituksen lähiruokaohjelma ja lähiruokasektorin kehittämisen tavoitteet vuoteen 2020. Helsinki: Maa-ja metsätalousministeriö.

McEachern, M. G., Warnaby, G., Carrigan, M. \& Szmigin, I. 2010. Thinking locally, acting locally? Conscious consumers and farmers’ markets. Journal of Marketing Management 26: 395-412.

Niva, M., Mäkelä, J., Kahma, N. \& Kjærnes, U. 2014. Eating sustainably? Practices and background factors of ecological food consumption in four Nordic countries. Journal of Consumer Policy 37: 465-484.

Orth, U. R. \& Firbasova, Z. 2003. The role of consumer ethnocentrism in food product evaluation. Agribusiness 19: 137-153.

Papadopoulos, N., Heslop, L. \& Bamossy, G. 1990. A comparative image analysis of domestic versus imported products. International Journal of Research in Marketing 7: 283-294.

Peltoniemi, A. \& Yrjölä, T. 2012. Kuluttajien ja tuottajien näkemyksiä ruoan ostopäätöksistä ja tuotantotavoista. Työselosteita ja esitelmiä 138. Helsinki: Kuluttajatutkimuskeskus.

Piiroinen, S. \& Järvelä, K. 2006. Kokemuksella ja laadulla. Tutkimus kuluttajien ruoan valinnasta. Kuluttajatutkimuskeskuksen julkaisuja 8/2006. Helsinki: Kuluttajatutkimuskeskus.

Pouta, E., Heikkilä, J., Forsman-Hugg, S., Isoniemi, M. \& Mäkelä, J. 2010. Consumer choice of broiler meat: The effects of country of origin and production methods. Food Quality and Preference 21: 539-546. Regattieri, A., Gamberi, M. \& Manzini, R. 2007. Traceability of food products: General framework and experimental evidence. Journal of Food Engineering 81: 347-356.

Roininen, K., Arvola, A. \& Lähteenmäki, L. 2006. Exploring consumers’ perceptions of local food with two different qualitative techniques: Laddering and word association. Food Quality and Preference 17: 20-30.

Schnettler, B., Horacio, M., Lobos, G., Sepulveda, J. \& Denegri, M. 2011. A study of the relationship between degree of ethnocentrism and typologies of food purchase in supermarkets in central-southern Chile. Appetite 56: 704-712.

Shankarmahesh, M. N. 2006. Consumer ethnocentrism: an integrative review of its antecedents and consequences. International Marketing Review 23: 146-172.

Sharma, S., Shimp, T. A. \& Shin, J. 1995. Consumer ethnocentrism: a test of antecedents and moderators. Journal of the Academy of Marketing Science 23: 26-37.

Shimp, T. A. \& Sharma, S. 1987. Consumer ethnocentrism: construction and validation of the CETSCALE. Journal of Marketing Research 24: 280-289.

Tilastokeskus 2016. Tietokanta: väestörakenne. Saatavilla: www.tilastokeskus.fi (haettu 17.05.2016).

Tirelli, C., Martínez-Ruiz, M. P. \& Gómez-Ladrón-De-Guevara, R. 2016. Assessing the impact of ethnocentrism in the food buying decisions of international university students. Journal of Food Products Marketing 22: 279-303.

Valtioneuvosto 2013. Ruoka2030: Suomi-ruokaa meille ja maailmalle. Valtioneuvoston selonteko ruokapolitiikan linjauksista vuoteen 2030.

Wang, C. \& Chen, X. Z. 2004. Consumer ethnocentrism and willingness to buy domestic products in a developing country setting: testing moderating effects. Journal of Consumer Marketing 21: 391-400. 